【原著】

\title{
コラーゲン含有飲料摂取による顔面皮膚性状の変化 Change in Facial Skin Quality after Consuming a Collagen Containing Beverage
}

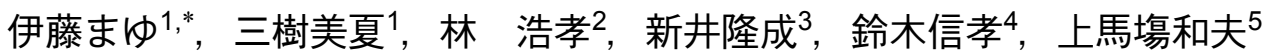 \\ Mayu ITO ${ }^{1,{ }^{*}}$, Mika MIKI ${ }^{1}$, Hirotaka HAYASHI ${ }^{2}$, Takanari ARAI ${ }^{3}$, \\ Nobutaka SUZUKI ${ }^{4}$, Kazuo UEBABA ${ }^{5}$ \\ ${ }^{1} \mathrm{M}$ 's クリニック南麻布 \\ 2 金沢大学イノベーション創成センター \\ 3 金沢大学大学院医学系研究科周生期医療専門医養成学講座 \\ ${ }^{4}$ 金沢大学大学院医学系研究科臨床研究開発補完代替医療学講座 \\ 5 富山大学和漢医薬学総合研究所
}

【要 旨】

コラーゲン含有飲料の 1ヶ月間摂取による顔 面皮膚の変化を, 計測機器による指標を使っ て予備的に検討した. 61 名の健常女性 (年齢

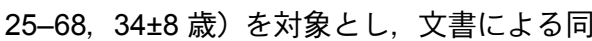
意を得た後,コラーゲン $5 \mathrm{~g}$ 飲料／日摂取群 (30 名) と $10 \mathrm{~g}$ 飲料 /日摂取群（31 名）に 無作為に割り付けし，摂取前と後 1 週目と

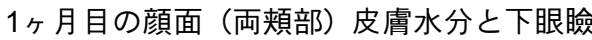
の函数を測定した. 皮膚水分と皺数に関して, 改善した反応例と変化がない無反応例に分類 したところ, $10 \mathrm{~g}$ 摂取群では $5 \mathrm{~g}$ 摂取群より 高い 5 割の反応率が得られた. 反応例は無反 応例より摂取前において皺数が多く皮膚水分 が低いこと，媰数は 1 週間目から有意な改善 をみることが示された. また本飲料が安全で あることも示された. 今後, 皮膚の異常性状 例を対象にして，コラーゲン $10 \mathrm{~g} /$ 日を， 1 週 間あるいは 1 ヶ月月間投与する二重盲検試験 により有効性を評価する研究の必要性が示さ れた.

【キーワード】

コラーゲン含有飲料, 顔面皮膚水分, 下眼瞼 蚼数
はじめに

20 世紀に入り，コラーゲン含有機能性食品の開発が進 んでいる. 元来コラーゲンは人体の組織, 細胞の周囲の 微小環境を形作る主要な構成要素の一つであり，細胞の 主機能と密接に関連していることが報告されている ${ }^{1,2)}$. 皮膚であれば，真皮層，血管などの構成成分となり，特 に真皮層ではその 90\%がコラーゲンで占められている2). しかしながら，紫外線や大気活染，ストレスなどにより 発生するフリーラジカルで攻撃されたり，加齢とともに 繊維芽細胞の活動性の低下などが原因となって，コラー ゲンやエラスチンなどの弾力繊維の生産量が低下する. そして，高齢者の皮膚の繊維芽細胞は，若年者の皮膚の 繊維芽細胞に比べ，その増殖能力が低下することが知ら れている。 また，コラーゲンは，5つの型（分子種）に 分類されているが，皮膚コラーゲンの $80 \%$ を占める I 型 コラーゲンの産生能力が加齢などにより低下したり，コ ラーゲンを分解するコラゲナーゼ産生能力が亢進するこ とで，真皮層が薄くなると石川ら ${ }^{3)}$ は述べている．これ らの研究から, 皮膚の生理的老化にコラーゲンが関与し ていることは疑いの余地がない. 肌の弾力性の低下をは じめとした老化を防ぐ一環として，コラーゲンを体内に いかに摂取するか，また，撕取したコラーゲンペプチド

受理日：2009年 5 月 13 日

* 干106-0047＼cjkstart東京都港区南麻布 5-2-9インスタイル南麻布ビルディング R-2FＴel: 03-5475-6770 Fax: 03-3280-7780 E-mail: itoh@ms-clinic.net 
を元に，他の材料とともに，コラーゲン生成を促すかが 鍵となってくる，それを狙って，種々のコラーゲン製剤 が創生され，機能性食品として普及している.

食品から摂取したコラーゲンの生体内での代謝や臨床 効果を明確にしている報告は少ないが，速水らの，動物 性コラーゲンペプチドを用いた試験で肌の弾力性が改善 もしくは維持の傾向を示し, 皮膚柔軟性が増加したとい ら報告 ${ }^{4)}$ や，菊地らによる，海洋性コラーゲンペプチド による皮膚の柔軟性が増加したといら報告5), 後藤らに よるコラーゲン $5 \mathrm{~g}$ 含有食品による肌の弾力性増加の報 告6) では，いずれも，皮膚の弾力性の増加が認められて いる.

今回の実験では，豚コラーゲンペプチドを主成分とし た飲料のコラーダン用量を $2 つ$ 設定し，健常成人女性を 対象に無作為に 2 群に割り付けて 1 ヶ月間摂取させた。 それによる顔面の肌に対する効果を調べるために，被験 者の主観的意見に加えて客観的なデータとしての評価を オープン試験により予備的に検討し考察を加えた。 今回 の結果から, 今後の二重盲検で行らランダム化比較試験 のための示唆を得た.

\section{材料・方法}

\section{1) 対象者}

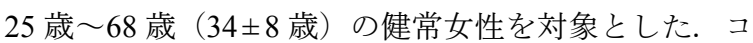
ラーゲン $5 \mathrm{~g}$ を毎日摂取する群 (30 名: $34 \pm 5$ 歳) と $10 \mathrm{~g}$

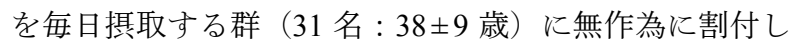
た。へルシンキ宣言の主旨にのっとり，被験者に十分な 説明と理解を得たうえで，文書による同意を取得し，日 本臨床自然療法研究会の倫理委員会の承諾の後試験を実 施した。

\section{2）試験飲料}

ロッテ健康産業株式会社製造の豚コラーゲン（ペプチ
ド）を主成分とした飲料（表 1 参照）で，コラーゲン $5 \mathrm{~g}$ 含有食品と $10 \mathrm{~g}$ 含有食品を使用した. 2006 年 10 月 25 日 ～ 2006 年 12 月 28 日の期間で， 1 ヶ月間摂取させた.

\section{3）皮膚性状の検査}

皮膚性状計測機器（(株）インフォワード製 Robo Skin Analyzer CS50）を使用し，顔面皮膚の表面の視覚的性状 （下眼瞼の㱀数）と両側煩部の皮膚水分を, コラーゲン含 有食品の摂取前, 拱取1週間後, 摂取一ヶ月後の各 3 回測 定した.

皮膚水分の測定原理は, 従来の 1 方向対称軸・静電容 量センサーを使ったものではなく, 従来のものより再現 性が高い 360 度中心対称性をもつ静電容量センサーを 使って, 誘電係数の違いにより静電容量を測定し，皮膚 水分の割合（0-99\%）を推定する方法によった.

まったく水分を含まないものが $0 \%$ ，コットンに水を 最大限にしみこませた場合は，99\%となる。下眼瞼の㱀 数は，下眼裂に沿った横のラインに対し，垂直な縦方向 に交差する㱀（溝）の本数を，視覚的に測定して求め, 左右の平均値を計算した。

な拈，少なくとも試験開始 1 週間前からは，個々で摂 取しているサプリメントがある場合は中止してもらい, 3 回目の測定までは，試験领料の久の摂取とした。 また， その他の化粧品や食事摂取については通常通りとした. さらに，顔面皮膚の検査では，全員に，当クリニックで 通常施術前に使用している洗顔料で洗顔をしてもらい, 他の基礎化粧品を使用せずに 15 分間の安静をとった後 に測定を行った.

以上に加え，一ヶ月間の摂取前後での体重の変化や自 覚的な变化を各被験者に測定，自由記載させた．

\section{4）統計解析}

拱取前と 1 週間目，一ヶ月目との比較には，Dunnett's $t$-test を行い, $5 \mathrm{~g}$ と $10 \mathrm{~g}$ 摂取群の摂取前值の比較には

表 1 コラーゲン含有飲料の組成

\begin{tabular}{|c|c|c|c|c|c|c|c|}
\hline & コラーゲン & 他の含有成分 & エネルギー & タンパク質 & 脂質 & 炭水化物 & $\mathrm{Na}$ \\
\hline $\begin{array}{l}\text { コラーゲン } 5 \mathrm{~g} \\
\text { 含有製剤 }\end{array}$ & $\begin{array}{l}\text { 豚皮由来コラーゲン } \\
\text { ペプチド } 5 \mathrm{~g}\end{array}$ & $\begin{array}{l}\text { りんご, 果糖, 酸味料, 香料, 安 } \\
\text { 定剂 (大豆多糖体) } \\
\text { 甘味料（アセスルファム } \mathrm{K}, \text { ステ } \\
\text { ビア, スクラロース, ビタミン } \\
\mathrm{P}, \text { ナトリウム) }\end{array}$ & $38 \mathrm{Kcal}$ & $5.0 \mathrm{~g}$ & $0 \mathrm{~g}$ & $5.0 \mathrm{~g}$ & $26 \mathrm{mg}$ \\
\hline $\begin{array}{l}\text { コラーゲン } 10 \mathrm{~g} \\
\text { 含有製剂 }\end{array}$ & $\begin{array}{l}\text { 豚皮由来コラーゲン } \\
\text { ペプチド } 10 \mathrm{~g}\end{array}$ & $\begin{array}{l}\text { りんご, 果糖, 酸味料, 香料, 安 } \\
\text { 定剂 (大豆多糖体) } \\
\text { 甘味料（アセスルファム } \mathrm{K} \text {, ステ } \\
\text { ビア, スクラロース, ビタミン } \\
\mathrm{P}, \text { ナトリウム) }\end{array}$ & $60 \mathrm{Kcal}$ & $10.0 \mathrm{~g}$ & $0 \mathrm{~g}$ & $6.2 \mathrm{~g}$ & $48 \mathrm{mg}$ \\
\hline
\end{tabular}

市販の製剤には, ビタミン C $100 \mathrm{mg}$ を含有するが, 本研究では, ビタミンCを抜いている. 
Student's $t$-test を, 両群における出現率の比較には $\chi^{2}$ 検 定を行った．いら゙れも $\mathrm{p}<0.05$ を有意水準とした。な技， 摂取 1 週間目に拈いて，前值の $110 \%$ 以上の皮膚水分増 加例を反応群，100\%以下の変化を示した例を，無反応群 とした，反応群にも無反応群にも含まれない例があるた め，双方を加えても，61 例にはなっていない，また，摂 取 1 週間目の下眼瞼皮膚の㱀数については, 100\%以上で 変化なしか，多くなった例を無反応群，99\%以下に減少 した例を，反応群として解析した。

\section{結 果}

\section{1） $5 \mathrm{~g}$ コラーゲン製剤摂取時の顔面皮膚水分の変化}

図 1 には, $5 \mathrm{~g}$ コラーゲン製剤 1 週間拱取前後での顔面 皮膚水分の変化について反応例と無反応例にわけて, 一ヶ月後までの変化を示した. 双方の群とも， 1 週間目 には有意な変化を認めるも, 一ヶ月後には, 摂取前値と の差は消失した $\left({ }^{++} \mathrm{p}<0.01,{ }^{+++} \mathrm{p}<0.001\right.$, Dunnett's $t$-test $)$. た，反応例と無反応例とで，それぞれの前值の間には有 意差を認めた $(* \mathrm{p}<0.05$, Student's $t$-test).

\section{2） $10 \mathrm{~g}$ コラーゲン製剤摂取時の顔面皮膚水分の変化}

図 2 には, $10 \mathrm{~g}$ コラーゲン製郕 1 週間摂取前後での顔 面皮膚水分の変化について反応例と無反応例にわけて, 一ヶ月後までの変化を示した．双方の群とも， 1 週間目 には有意な変化を認めるも，一ヶ月後には，摂取前值と の差は消失した $\left({ }^{++} \mathrm{p}<0.01,{ }^{+++} \mathrm{p}<0.001\right.$, Dunnett's $t$-test $)$. 反 応例と無反応例とで，それぞれの前值の間には有意差の 傾向を認めたのみであった (†p<0.1, Student’s $t$-test).

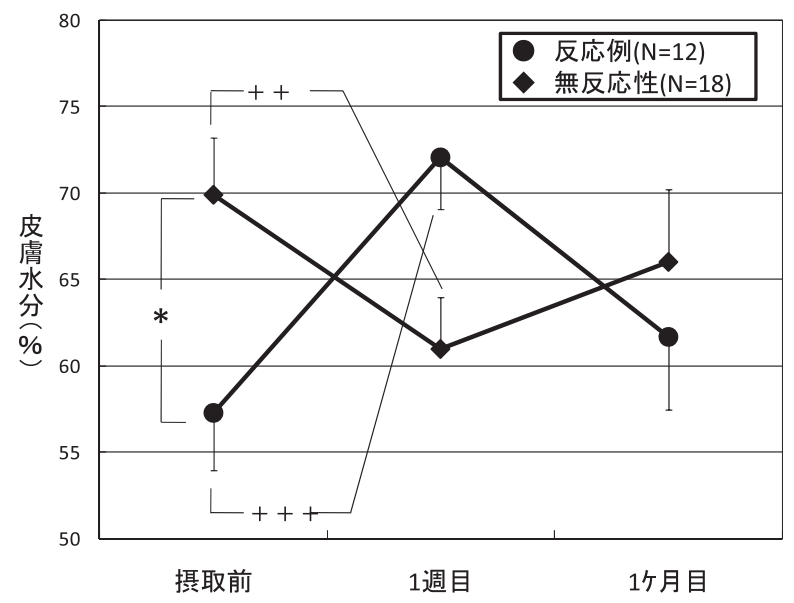

図 $15 \mathrm{~g}$ コラーダン製剤摂取時の顔面皮膚水分の変化 ${ }^{++} \mathrm{p}<0.01,{ }^{+++} \mathrm{p}<0.001$, Dunnett's $t$-test, ${ }^{*} \mathrm{p}<0.05$, Student's $t$-test. 反応例と無反応例のいずれにも含まれない被験者がいるため, 総数が 30 例になっていない.

\section{3） $5 \mathrm{~g}$ コラーゲン製剤摂取時の下眼瞼部皺数の変化}

図 3 には, $5 \mathrm{~g}$ コラーゲン製剂 1 週間摂取前後での下眼 瞼䀛数の反応例と無反応例にわけて，一ヶ月後までの変 化を示した．双方の群とも， 1 週間目には有意な変化を 認めるも，一ヶ月後には，無反応例は，拱取前值との差 は消失した $\left({ }^{++} \mathrm{p}<0.01,{ }^{+++} \mathrm{p}<0.001\right.$, Dunnett's t-test $)$. 反応例 と無反応例とで，それぞれの前值には有意な差はなかっ た。

\section{4） $10 \mathrm{~g}$ 製剂投与時の下眼瞼部皺数の变化}

図 4 には, $10 \mathrm{~g}$ コラーゲン製剂 1 週間摂取前後での下 眼瞼㵣の反応例と無反応例にわけて，一ヶ月後までの変 化を示した．双方の群とも，1 週間目には有意な変化を

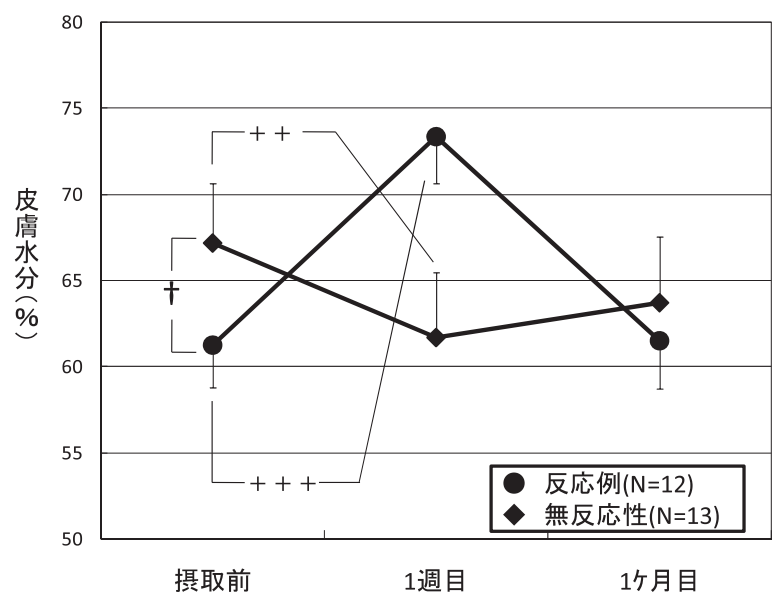

図 $210 \mathrm{~g}$ コラーゲン製剤拱取時の顔面皮膚水分の変化 ${ }^{++} \mathrm{p}<0.01,{ }^{+++} \mathrm{p}<0.001$, Dunnett's $t$-test, ${ }^{\dagger} \mathrm{p}<0.1$, Student's $t$-test. 反応例と無反応例のいずれにも含まれない被験者がいるため, 総数が 31 例になっていない.

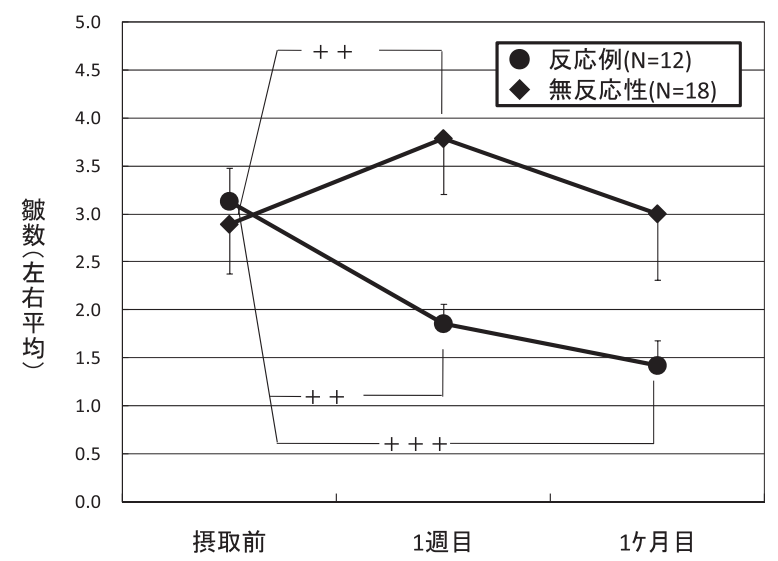

図 $35 \mathrm{~g}$ コラーゲン製剤摂取時の下眼瞼部媰数の変化 ${ }^{++} \mathrm{p}<0.01,{ }^{+++} \mathrm{p}<.001$, Dunnett's $t$-test.

反応例と無反応例のいずれにも含まれない被験者がいるため, 総数が 30 例になっていない. 
認めるも, 一ヶ月後には, 摂取前値との差は消失した $\left({ }^{+++} \mathrm{p}<0.0001\right.$, Dunnett's t-test). 反応例と無反応例とで，そ れぞれの前值には有意な差を認めた $(* * \mathrm{p}<0.01$, Student's $t$-test).

5） 1 週目における皮膚水分量増加，下眼瞼皺数減少例 の割合の比較

図 5 には, 1 週間コラーゲン製剤摂取前後での水分量 の増加例と, 下眼瞼㱀数減少例の割合を, $5 \mathrm{~g}$ と $10 \mathrm{~g}$ 摂 取とで比較した，それらの間の出現率には， $\chi^{2}$ 検定にて 有意差はなかったが，平均值では， $10 \mathrm{~g}$ 摂取群の方が大 きく, $10 \mathrm{~g}$ 摂取群の反応率はほぼ 5 割であった。

6）反応性と年齢，体重変化との関連性

表 2 には，皮膚水分と㱀数に関する反応，無反応群の

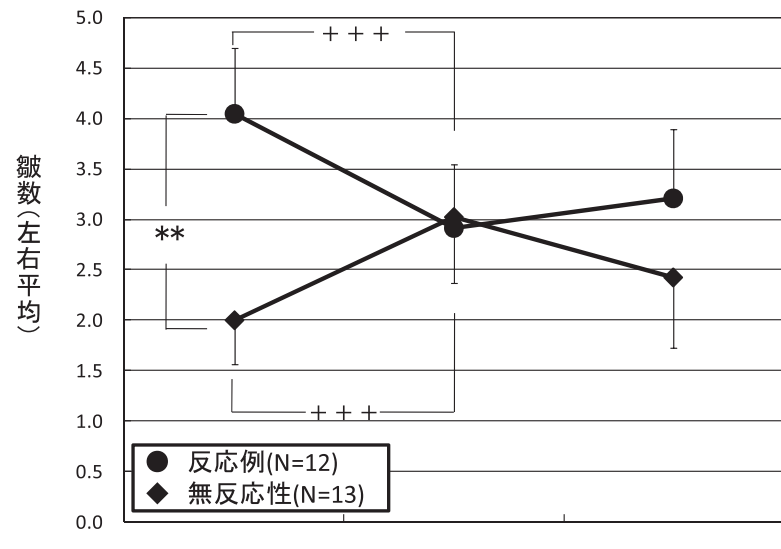
摂取前
1週目
1个月目

図 $410 \mathrm{~g}$ 製剂投与時の下眼瞼部㱀数の変化 ${ }^{+++} \mathrm{p}<0.0001$, Dunnett's $t$-test, ${ }^{* *} \mathrm{p}<0.01$, Student's $t$-test.

皮虞水分量の增加例の割合の比較 (1週目)

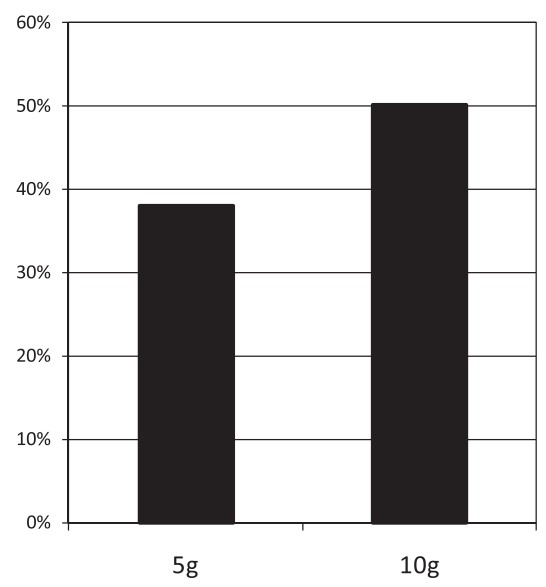

年齢比較を示すが，年齢は反応性を分けるものではな かった。また，年齢と皮膚水分，下眼瞼の㱀数の相関は， それぞれ $\mathrm{r}=0.13(\mathrm{p}<0.1), 0.41(\mathrm{p}<0.05)$ であった。

表 3 には，皮膚水分と㱀数に関する反応，無反応群の 体重変化比較を示すが，体重の変化との関連性はなかっ た.

7） 反応率のカットオフ値による違いと投与期間による 違い

次に，皮膚所見の異常基準として，株式会社インフォ ワード調べによる肌年齢早見表に従って，被数について は，30 あるいは 35 歳以上の值を，水分については，40 あるいは 60 歳以上の値をカットオフ値にして,カットオ フ值の上下での反応率の差を， $5 \mathrm{~g}$ と $10 \mathrm{~g}$ 摂取群につい て比較した（表 4).カットオフ値については，今回の参

表 2 皮膚水分と㱀数に関する反応，無反応群の年齢比較

\begin{tabular}{clcc}
\hline $\begin{array}{c}\text { コラーゲン } \\
\text { 撕取量 } / \text { 日 }\end{array}$ & \multicolumn{1}{c}{ 反応例 } & $\begin{array}{c}\text { 皮膚水分 } \\
(\%)\end{array}$ & 㱀数 \\
\hline \multirow{2}{*}{$5 \mathrm{~g}$} & 反応例年齢 & $33 \pm 6$ & $35 \pm 6$ \\
& 無反応例年齢 & $35 \pm 6$ & $34 \pm 5$ \\
& 反応例年齢 & $39 \pm 7$ & $40 \pm 11$ \\
& 無反応例年齢 & $40 \pm 13$ & $37 \pm 7$ \\
\hline
\end{tabular}

表 3 皮膚水分と㱀数に関する反応，無反応群の体重変化比較

\begin{tabular}{clrr}
\hline $\begin{array}{c}\text { コラーゲン } \\
\text { 摂取量 } / \text { 日 }\end{array}$ & 反応例 & $\begin{array}{c}\text { 皮膚水分 } \\
(\%)\end{array}$ & \multicolumn{1}{c}{ 被数 } \\
\hline \multirow{2}{*}{$5 \mathrm{~g}$} & 反応例体重変化 $\mathrm{kg}$ & $-0.2 \pm 0.7$ & $-0.4 \pm 1.1$ \\
& 無反応例体重変化 $\mathrm{kg}$ & $0.2 \pm 1.1$ & $0.3 \pm 0.5$ \\
& 反応例体重変化 $\mathrm{kg}$ & $0.2 \pm 0.4$ & $0.1 \pm 0.3$ \\
& 無反応例体重変化 $\mathrm{kg}$ & $0.0 \pm 0.0$ & $0.2 \pm 0.4$ \\
\hline
\end{tabular}

下眼瞼しわの短縮例の割合の比較 （1週目）

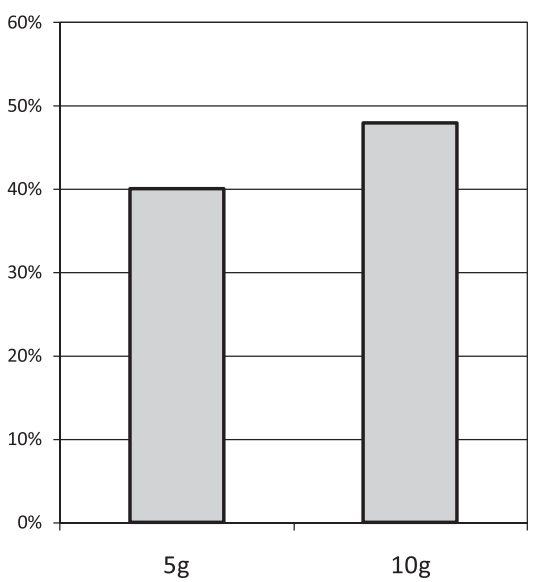

図 51 週目に打ける皮膚水分量増加, 下眼瞼㱀数減少例の割合の比較 
加者の平均年齢を考慮して 30〜35 歳の值にしたが, 皮膚 水分については, 35 歳の值をカットオフ值にすると解析 する場合例数が少なくなったので，40 あるいは 60 歳の 值を仮にとりあげた．カットオフ值による反応例と無反 応例の出現率を比較したところ, 摂取後 1 週間目におい $\tau, 10 \mathrm{~g}$ 膝取例では, 㱀数が 2.5 あるいは 3.0 以上と以下 の例で分けると反応率が 7 割と約 2 割とで有意に分別で きた．また，皮膚水分については， 60 以下と 61 以上と で分けると，それぞれ反応例が 7 割と 3 割半となり，有 意に分別できた，ただし，いら゙れの群でも一ヶ月後には 反応率は低下した。

\section{8）自由記載結果}

$5 \mathrm{~g}$ 摂取群では, 1 週目で 12 例 $/ 30$ 例 $(40 \%)$, 一ヶ月 目で 22 例 $/ 30$ 例（73\%）に扔いて，肌荒れがなくなっ た，もちもち感がでてきた，肌の調子が良くなり吹き出 物が出なくなった，乾燥しなくなった，肌のきめが良く
なったような気がする，唇が割れない，化粧のりがよく なった気がする，肌のッヤ感が出て来た，手荒れが沶さ まった，朝扔腹がすくようになった，毛穴が小さくなっ た気がする，肌のハリが出て来たよらな気がするなどの 肯定的な感想が得られた。

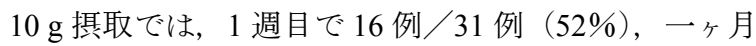
目で 22 例 $/ 31$ 例（71\%）に沶いて，肌が潤い柔らかく なった，化粧ノリが良くなった，乾燥しなくなった気が した，肌がすべすべしてきた，肌荒れや乾燥する時期た が今期はなかった，メイクを落としや洗顔のあとプルっ としている, 弾力がでてきた, 洗顔後の乾燥が少なくなっ た，顎や鼻下がカサカサする時期だが今期はなかった， メイク崩れしなくなった，化粧水をつけたあとの感じが よくなった，顔だけでなく身体の乾燥も少なくなった， 肌のハリが出て来た感じ，などの肯定的な感想が得られ た。

副作用的な訴えとしては， $5 \mathrm{~g}$ 摂取ではなかったが，

表 4 反応率のカットオフ值による違いと投与期間による違い

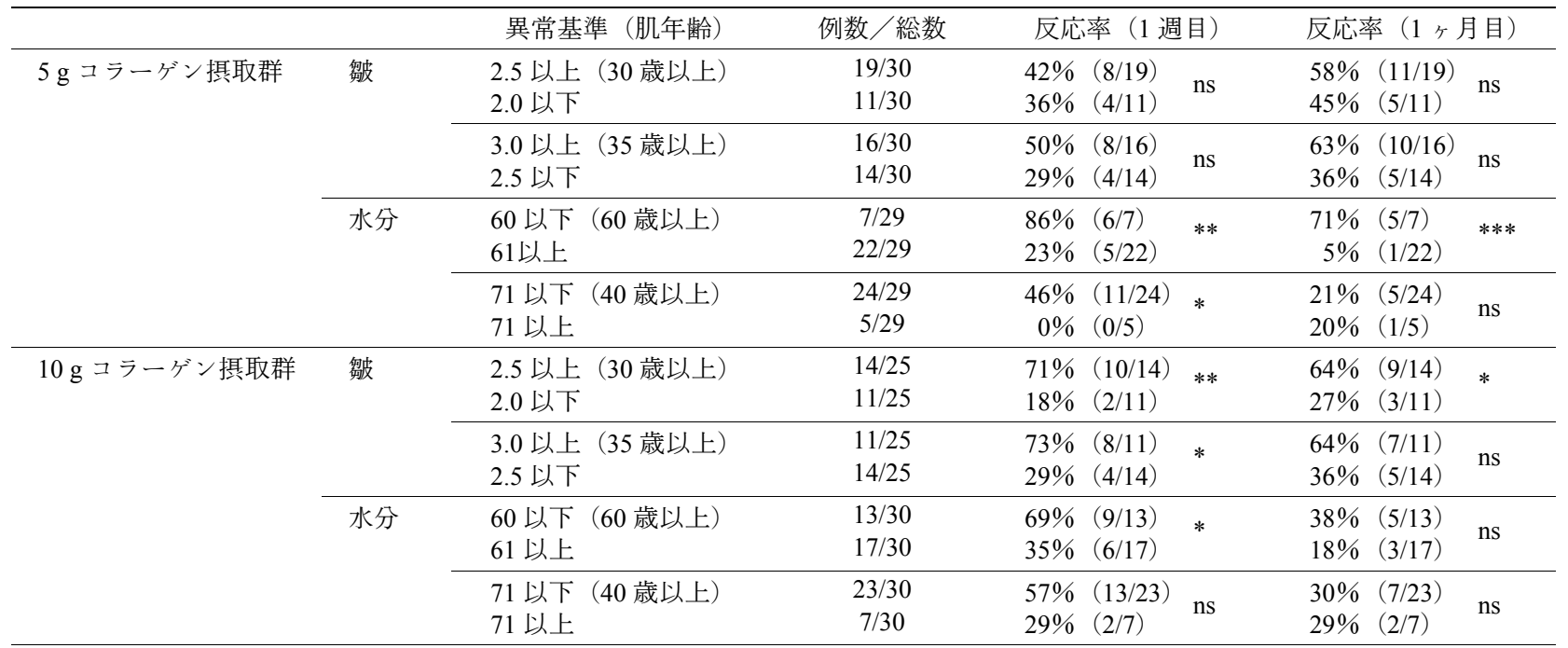

注）例数は，当該検查が解析できなかった例は，除外したため，総数が 61 例あるいは，30，31 例になっていない. ns: not significant（有意差なし）， $\chi$ 二乗検定 $* \mathrm{p}<0.05, * * \mathrm{p}<0.01$

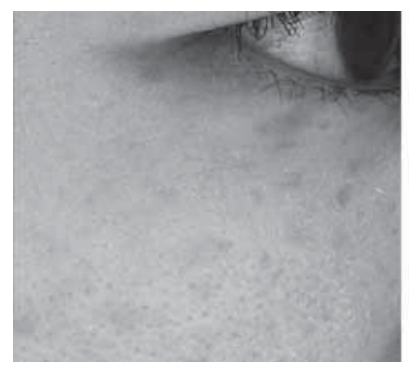

摂取前

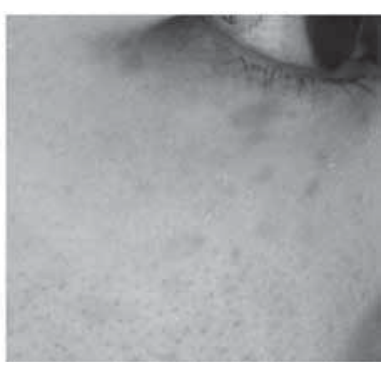

摂取後

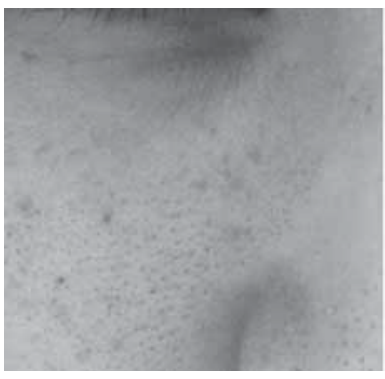

摂取前

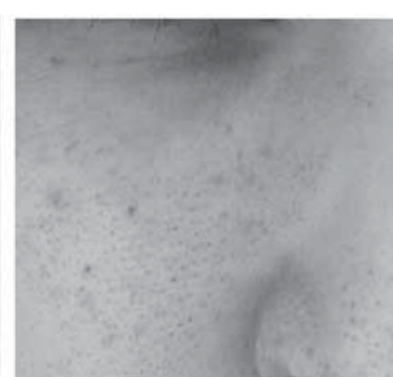

摂取後 
$10 \mathrm{~g}$ 摂取群で 1 例 $/ 31$ 例（3\%）で， 1 週間目に，「屯く んだ (下肢)」，一ヶ月後には，「息切孔するようになった 感じがする」と訴えた例であった，ただし，本例では体 重には変化はなく, 生活に支障を起こす程度でもなかっ た，そして，その後摂取期間が終了した後，改善をみて いる。 な拉, 図 6 と 7 には, 下眼瞼拫数の減少について 肉眼的にも明らかな例を紹介する. 双方とも，摂取後 1 週間目には，顔面全体の赤味やキメなども改善し，自覚 的にも化粧ののりが良くなったと自覚していた上，計測 機器による測定結果では, 下眼瞼の㱀数の顕著な減少を みた。

\section{考 察}

コラーゲン含有飲料における人体への影響に関する報 告は少ないが, 前述のように速水らによる, 動物性コラー ゲンペプチドを用いた研究報告4) や，菊地らによる，海 洋性コラーゲンペプチドによる皮膚の柔軟性の増加の報 告5), 後藤らによるコラーゲン $5 \mathrm{~g}$ 含有食品による肌の弾 力性増加の報告6) では, いずれも，皮膚の弾力性の増加 が認められている。 また，動物実験に沶いて子卵巣摘出 モデルラットを使った野村らの報告7) にあるように，皮 膚への肯定的な影響が報告されている.

今回の実験では，豚コラーゲンペプチドを主成分とし た飲料（表 1）を健常成人女性に摄取させて，顔面皮膚 水分量と顔面皮膚のしわを，皮膚性状計測機器を使った 客観的方法にて， $5 \mathrm{~g}$ あるいは $10 \mathrm{~g}$ コラーゲン含有飲料 の顔面皮膚性状への作用を測定した。そ結果，被験者 全員で解析したところ，摂取前後での顔面皮膚水分の有 意な変化を見出すことができなかった。 しかし，皮膚水 分が摂取後 1 週間目に $110 \%$ 以上増加した例，あるいは 下眼瞼皮膚の㱀数が減少した例を，反応群とし，皮膚水 分が $100 \%$ 以下に減少したり, 㱀数が $100 \%$ 以上に増加し た例を無反応群として解析したところ, 反応群と無反応 群では, 特に $10 \mathrm{~g}$ 製剂摂取前の值で有意差が認められ た．つまり反応例と無反応例のプロフィールが異なると いらことである.

また，表 4 に示すように，カットオフ值による反応例 と無反応例の出現率を比較したところ, 拱取後 1 週間目 において $10 \mathrm{~g}$ 摂取例では, 䖰数が 2.5 あるいは 3.0 以上 と以下の例を分けると反応率が 7 割と約 2 割とで有意に 分別できた。 また，皮膚水分が， 60 以下と 61 以上を分 けると, 反応例が 7 割，無効例が 3 割半となり，有意に 分別できた。これは，皮膚が乾燥したり，㱀が多い例の 方が，コラーダン含有飲料の影響が高く出ることを示唆 する結果である．今回の参加者には若い女性から高齢の
女性までの健常女性が参加して打り，様々な皮膚の状態 の例が参加していたと推定される。その中で皮膚の状態 が悪い例で効果があり，良い例には効果が少ないことを 示す今回の結果は非常に興味深いものである.

今回の被験者の 1 週間後に打いて，有意な皮膚水分量 の増加や皮膚の㱀数の減少を認めた例では，体重の有意 な変化は認められていないことから，浮腫で皮膚水分が 増加したためとは考光にくい. 特に年齢が若くて皮膚水 分が高い被験者で効果が少なかったことから，生理前の 浮腫状態などが関与したことも考劣にくい. 毎日, コラー ゲン生成のための元となるコラーゲン構成ペプチドやア ミノ酸を摂取したため，真皮層などでのコラーゲン繊維 の生成が促され，真皮層の保水性が増したことが推定さ れる. また, 下眼瞼の㱀数の減少については, 皮膚水分が 増加して，下眼瞼などの皮膚が薄くて皮膚水分によって 影響されやすい場所に影響が出現したためと推定できる。

皮膚水分の測定は，室内の湿度などの影響を通常受け やすく，今回使用した機器は，再現性を高めたものでは あるが，測定場所が医療機関の検査室といら湿度環境に ついては恒常的な状態を維持することが困難であること を考慮すべきであろう。しかし，反応群の一ヶ月後まで の変化を追跡すると, 1 週間後には反応していても,一ヶ 月後には, 皮膚水分は, $5 \mathrm{~g}$ と $10 \mathrm{~g}$ 摂取群の双方で摂取 前值に復している（図 1 と 2).

一方，皮膚の㱀数については，視覚的な測定であり， 客観性が高い.今回, $5 \mathrm{~g}$ 摂取群では, 1 週間から有意に 改善し，一ヶ月後も維持された（図 3). $10 \mathrm{~g}$ 拱取群でも， 1 週間目で有意な改善をみた（図 4).

自覚的には, 1 週間, 一ヶ月と効果を体感する比率が 増加して打り，それと皮膚水分量の変化とが相関してい ないことは，皮膚水分量の測定法が，水分自体を測定し ているものではないためと推定される。しかし，より客 観性に優孔る㱀の数は, 自覚的な変化之相関して打り, 本製剂での皮膚への効果が 1 週間目から出現する可能性 を示唆するものであろう。

ただ，今回，盲検試験でないオープン試験で行ったた めに，ヒト試験では問題になるプラセボ効果が主観的評 価に影響したことは当然考只らる。特に自由記載記録 では，1 週間後に $5 \mathrm{~g}$ で $40 \% ， 10 \mathrm{~g}$ 摂取群で $52 \%$ で肯定 的変化を訴光たが，一ヶ月目には，双方とも約 70\%程度 で肯定的変化を訴えている。 しかし，5g摂取時の自覚的 変化の記録と皮膚㱀数とは類似した傾向を示して扣り, 皮膚水分測定法の信頼性の問題も考慮すると, 今後の, 二重盲検試験の必要性が支持される，特に，皮膚性状の 異常な被験者を対象にして行ら二重盲検試験が必要であ 万う. 
今回の被験者で $10 \mathrm{~g}$ 摂取群の 1 例 $(3 \%)$ 飞おいて, 下 肢のむくみや息切孔を訴えているが，生活に支障をきた 寸程度ではなく、コラーゲン製剤に中止により改善して いることから，本製剤の安全性に問題があるとは言えな い.

食事から，健常人が日常的に大量のコラーゲンペプチ ドを摂取することは，現実的に難しいことであるので， 今回のよらに経口摂取したコラーゲンペプチドが, 生体 に対して安全性を示し，生体の状況に応じて皮膚性状に 肯定的な影響を与えることを示す研究結果は非常に興味 深いものであり, 今後のコラーゲン製剂のランダム化比 較試験を実施する場合に大きな示唆を与えてくれるであ ろう。

\section{結 論}

コラーゲン含有食品のオープン試験において, 反応例, 無反応例を分類し, 時間的な経過による解析を行ったと ころ, 皮膚の水分量が少なく, 㱀の多い被験者が，コラー ゲン製剤に対する反応性が高いことが示唆された。また $10 \mathrm{~g}$ 摂取までの安全性に大きな問題はないことも示唆さ 孔た. このような反応例, 無反応例に層別解析する方法 はこれまで報告されていないが，今後のコラーゲン製剤 の二重盲験ランダム化比較試験に打ける示唆を与えてく れた。

つまり，皮膚が乾燥して㱀数が多い被験者を対象にし て, 性周期の期間でも，皮膚水分量が比較的安定してい る卵胞期（生理開始後 2 週間以内や低温相）に, $10 \mathrm{~g}$ ב ラーゲン摄取を 1〜2 週間, 二重盲検ランダム化比較試験 として行わせながら, 皮膚性状の客観的評価法やコラー ゲン代謝の指標を測定することが必要と思われた.

あるいは，長期間摂取による慣れの減少の有無之機序
を明らかにするためには，コラーゲンのみの製剤だけで なく、ビタミン Cを補ったコラーゲン製剂，さらに対照 製剂の 3 群で，1-2 ヶ月間の二重盲検ランダム化比較試 験を行い, 性周期の同じ時期に毎月 1 回の皮膚検查を行 らなどが必要であららと考兄られた。

\section{謝 辞}

今回の予備的研究は, 口ッテ健康産業株式会社による 研究助成金により行われた。

\section{参 考 文 献}

1) 中邨智之. 血管細胞外基質と老化. 分子血管病. 2002;3(5): 27-34.

2) 大島 章. 血管壁のコラーゲン分子種. 結合組織. 1983-5; 15(1): 30-34.

3) 石川 治. 皮膚科医からのアンチエイジングアドバイス 抗加龄医療一診断と治療の最前線 / (治療法 / B. 各論) . Modern Physician 2006; 26(4): 571-574.

4) 速水耕介.コラーゲンペプチド含有领料の健常者における 皮膚粘弾性への影響. 新薬と臨床. J New Rem \& Clin 2000; 49(9): 867-873.

5) 菊地数晃, 又平芳春. 七上の乾燥肌抢よび肌荒机に対する 海洋性コラーゲンペプチド含有领料の有用性. FREGRANCE JOURNAL 2003; 9: 97-102.

6) 後藤祥二, 徳永隆久.「ダイエット\&コラーゲン」のダイ エット効果, 美肌効果扔よび安全性. 新薬と臨床. J New Rem \& Clin 2006; 55(12): 87-101.

7) 野村義宏，大橋啓吾，渡部陸人，春日井昇平．若年及び老 年卵巣摘出モデルラットの比較一サメコラーゲンの影響. 理学療法学. 2003; 30: 119.

8) 乃木田俊辰，川島 眞. ロボスキンアナライザーによるし わ治療の評価. 臨床皮膚科. 2005; 59（5增）：77-80.

9) 山田秀和. 皮膚とアンチエイシシング. 日本抗加齢学会雑誌. 2007; 3(4): 447-458（ロボスキンアナライザー文献）. 


\author{
ABSTRACT

\section{Change in Facial Skin Quality after Consuming a Collagen Containing Beverage} \\ Mayu ITO $^{1}$, Mika MIKI ${ }^{1}$, Hirotaka HAYASHI ${ }^{2}$, Takanari ARAI ${ }^{3}$, Nobutaka SUZUKI ${ }^{4}$, Kazuo UEBABA ${ }^{5}$ \\ ${ }^{1}$ M's clinic Minamiazabu \\ ${ }^{2}$ Center for Innovation, Kanazawa University \\ ${ }^{3}$ Endowed Center for the Advancement of Pregnancy, Perinatal and Infant Care, \\ Kanazawa University Graduate School of Medical Science \\ ${ }^{4}$ Department of Complementary and Alternative Medicine Clinical Research and Development, Kanazawa University \\ ${ }^{5}$ Department of Presymptomatic Health Promotion, Institute of Natural Medicine, University of Toyama
}

We conducted a preliminary study of the facial skin-improving effects of collagen-containing beverages as evaluated by objective indices. After obtaining written informed consent, 61 healthy females (age: $25-68,34 \pm 8$ y.o.) were randomly divided into two groups, receiving beverages containing $5 \mathrm{~g}(\mathrm{~N}=30)$ and $10 \mathrm{~g}(\mathrm{~N}=31)$, respectively, of collagen daily for one month. Facial skin moisture content and lower eyelid wrinkles were assessed before, 1 week and 1 month after consuming the test beverages. Results were analyzed of the $5 \mathrm{~g}$ and $10 \mathrm{~g}$ groups, as well as responder and non-responder groups. $10 \mathrm{~g}$ collagen beverages showed $50 \%$ effectiveness, and were more effective than the $5 \mathrm{~g}$ beverage; the effect was observable within 1 week. Furthermore, subjects with more wrinkles and drier skin showed greater benefit than those with higher facial skin moisture content and/or fewer wrinkles. It is suggested that a beverage containing $10 \mathrm{~g}$ collagen should be used for aged subjects with more wrinkles and/or drier skin for a period of 1-2 months in future randomized placebo-controlled trials of collagen-containing beverages.

Key words: collagen-containing beverage, facial skin moisture content, lower eyelid wrinkles 